\title{
Exploring Relationships between Demersal Resources and Environmental Factors in the Ionian Sea (Central Mediterranean)
}

\author{
G. D’Onghia, A. Giove, P. Maiorano, R. Carlucci, M. Minerva, F. Capezzuto, L. Sion, \\ and A. Tursi
}

Department of Biology, University of Bari “Aldo Moro”, Via E. Orabona 4, 70125 Bari, Italy

Correspondence should be addressed to G. D’Onghia, g.donghia@biologia.uniba.it

Received 21 December 2011; Accepted 20 February 2012

Academic Editor: Jakov Dulčić

Copyright (c) 2012 G. D’Onghia et al. This is an open access article distributed under the Creative Commons Attribution License, which permits unrestricted use, distribution, and reproduction in any medium, provided the original work is properly cited.

\begin{abstract}
The relationships between the abundance of demersal resources, environmental variables, and fishing pressure in the northwestern Ionian Sea in the last two decades were evaluated. Data on the density collected during seventeen trawl surveys carried out from 1985 to 2005 were used. The following species were considered: Aristaeomorpha foliacea, Nephrops norvegicus, and Parapenaeus longirostris for crustaceans; Merluccius merluccius, Phycis blennoides, and Mullus barbatus for teleost fish. The recruitment index was also considered for N. norvegicus, P. longirostris, M. merluccius and Mullus barbatus. Six candidate models were evaluated for each density and recruitment data set either combining fishing effort with global (NAO) and regional (SST and precipitation) climatic indices, or models separately involving fishing effort, NAO, or regional climatic indices as the only predictive variable. Model selection was carried out using an information-theoretical approach that applies Akaike's Information Criterion (AIC). High changes over time were observed for the density data and recruitment indices in each species. Apart from hake abundance and recruitment data, for which a clear positive relationship with the NAO index alone was detected, the changes observed in the other species seem to be the consequence of the interaction between bottom-up effects linked to changes in physical environment and top-down ones due to the fishing pressure.
\end{abstract}

\section{Introduction}

It is well known that the abundance of the aquatic population fluctuates over both spatial and temporal scales in relation to the variability of abiotic and biotic factors in the ecosystem as well as to human activities, such as fishing [1-3]. Larkin [4] reported that the management of marine fisheries according to ecosystem properties is essentially a question of distinguishing the impacts of fishing (top-down effects) from those of fluctuations in the environment (bottom-up effects), understanding the dynamics of species interactions and appreciating the way in which fishing fleets will respond to changes in the abundance of various stocks. However, Larkin [4] himself reported that, although changes in many marine ecosystem have no doubt occurred, efforts to model their holistic dynamics have not yet been successful due to the number of variables involved and the way in which only small errors in their estimation may lead to large effects in the simulated results.
Since 1985 demersal resources in Italian waters have mostly been monitored by scientists in the context of the GRUND project [5] and successively as part of MEDITS project [6]. In this respect, governments and stakeholders ask scientists to provide their best advice, in terms of indicators and reference points that should trigger management action. Most Mediterranean demersal resources show high fluctuations over time and are considered to be particularly susceptible to overexploitation [7]. Their management is based on "effort control" measures, including licence limitation, timearea closure, and gear restrictions [8].

At the end of the 1980s the Mediterranean Sea underwent a major change that encompassed atmospheric, hydrological, and ecological systems and that led to new regime conditions [9-11]. The most important and evident phenomenon that involved the change in circulation and thermo-haline properties of the water masses is the so-called Eastern Mediterranean Transient (EMT), corresponding to the shift 
in deep water formation in the eastern basin from its usual source in the southern Adriatic to a new source in the Aegean Sea [12-15]. Even though such a change included the whole Mediterranean, some basins such as the Ionian, Adriatic, and Levantine basin were primarily involved. During the EMT highly saline ( $>39.0 \mathrm{psu}$ ), warmer (around $15^{\circ} \mathrm{C}$ ) and welloxygenated intermediate waters flowed from the Aegean Sea through the Western Cretan Arc Straits. This flux interrupted the traditional path of Levantine Intermediate Waters (LIW) spreading northwards into the Ionian Sea and eastwards into the Levantine basin and affecting the dynamics of the upper, intermediate, and deep layers. During the EMT an uprising of the nutrients close to the euphotic zone occurred in the northern and eastern Ionian $[12,15]$. This large modification in the eastern Mediterranean circulation lasted approximately 10 years, until 1997 when the general Ionian cyclonic circulation was restored $[15,16]$. This change in circulation of the north Ionian gyre from cyclonic to anticyclonic and vice versa has been recently suggested as an internal process occurring between Adriatic and Ionian water masses on a decadal scale called Bimodal Adriatic-Ionian Oscillations (BiOS) [17].

The EMT-BiOS-related regime shift recorded in the early 1990s involved sea surface temperature, sea level pressure, surface and deep circulation of water masses, salinity and nutrient changes, affecting the primary production, and pelagic community as recorded by long-term studies on mucilage, red tides, plankton, jellies, and anchovies in the western and eastern Mediterranean basins [18-20]. In particular, changes in the standing stock of the autotrophic biomass and zooplankton abundance with consequent changes in the pelagic community structure were detected in both the Ionian Sea [21-24] and Adriatic and Ligurian seas $[18,19,25]$. The inversion of the surface currents in the Ionian Sea was also thought to influence the occurrence of species in the Adriatic Sea, including the first record of the scleractinian coral Astroides calycularis and the teleost fish Sparisoma cretense in this basin [26]. Civitarese et al. [18] reported a list of biological records in the Adriatic indicating that the presence of Atlantic and western Mediterranean species was concomitant with the anticyclonic north Ionian gyre and thus with advection of Modified Atlantic Waters (MAW) into the Adriatic, while the occurrence of Lessepsian species coincided with the cyclonic north Ionian gyre that advects eastern Mediterranean waters into the Adriatic.

The first finding of the tropical fish Sphoeroides pachygaster [27], Elates ransonnetii [28], and Dysomma brevirostre [29] in the Ionian Sea was suggested by Maiorano et al. [30] as a consequence of the water masses variations occurring in the Ionian basin during EMT-BiOS. Moreover, these authors reviewed the changes of demersal species abundance and faunal assemblage structure over the last twenty years. The causes of these changes were suggested to be linked to the interaction between the bioecology of the species and environmental factors as well as fishing pressure in the study areas. However, no direct relationships between environmental variables and species abundance changes were examined. With this regard, this work represents an attempt to evaluate the relationships between the abundance of demersal resources and environmental variables and fishing pressure in the north-western Ionian Sea in the last two decades.

\section{Material and Methods}

2.1. Data Collection. The geographic area considered in this work is the north-western Ionian Sea, along the Italian coasts (Figure 1). The time series data utilized cover the period 1985-2005. On the basis of Conversi et al. [19] who report the significant change of several climatic indicators (SST, SLP, NAO index, and NHT) in the years 19861988, the sea surface temperature (SST) of the Ionian Sea was selected as an indicator of environmental changes in this basin. Temperature is one of the primary factors in determining the distribution pattern and abundance changes in aquatic populations [31-36]. SST data were obtained using the AVHRR (advanced very high-resolution radiometer) (http://podaac.jpl.nasa.gov/). Since the variations of the North Atlantic Oscillation (NAO) influence the weather on a large scale over the North Atlantic and Europe and have a strong impact on the oceanic conditions, including the Mediterranean region, the winter NAO index was taken from $\mathrm{http} / / / \mathrm{www} . c g d . u c a r . e d u /$. The precipitation values (in $\mathrm{mm}$ ), often correlated to the NAO apart from local weather conditions, were recorded from http://www.ilmeteo.it/. The values of SST, NAO index, and autumn precipitation recorded between 1985 and 2005 are presented in Figure 2.

Fishing effort is an important variable influencing the abundance of living resources [1-3]. However, this is a complex variable that is difficult to quantify because it is influenced by different factors. The main fisheries of the north-western Ionian Sea are Gallipoli, Taranto, and Crotone (Table 1) (http://www.irepa.org/). Different fishing gears are used to exploit the demersal resources; however, trawling is the main technique in terms of catch and gross tonnage (GT). The trawlers are equipped with otter trawl nets. Fishing generally occurs from Monday to Friday during daylight hours only. Trawlers generally work on daily trips. Commercial hauls are carried out at different depths, from coastal waters to $700-800 \mathrm{~m}$. The management of the fisheries is based on effort control and mesh size regulation. Since 1988 a 3045-day "closed season" for trawling has been implemented in late summer-early autumn, as a management measure imposed by the Italian government [30,37]. As in most Mediterranean fisheries data on effort are almost absent and there is a low level of enforcement of the legislation [8]. In the present study the number of days-at-sea per year has been used as a measure of fishing effort. This may be a fair measure of fishing effort for demersal gears [38]. Nonworking days were made up of days closed by management, days with wind speeds $>15$ knots, public holidays, Saturdays, and Sundays. The wind intensity values were obtained from http://www.ilmeteo.it/. The trend of days-at-sea over time is presented in Figure 3.

Data on the demersal resources used in this work were collected during seventeen trawl surveys carried out in the north-western Ionian Sea, from 1985 to 2005, as part of 
TABLE 1: Number of vessels and mean gross tonnage (GT) for different gears recorded in the main fisheries (Gallipoli, Taranto, and Crotone) of the north-western Ionian Sea.

\begin{tabular}{lcccccccc}
\hline \multirow{2}{*}{ Fisheries } & \multicolumn{2}{c}{ Trawling } & \multicolumn{2}{c}{ Longline } & \multicolumn{2}{c}{ Gillnet } & \multicolumn{2}{c}{ Purse seine } \\
& N. vessels & Mean GT & N. vessels & Mean GT & N. vessels & Mean GT & N. vessels & Mean GT \\
\hline Gallipoli & 75 & 11.61 & 16 & 8.22 & 313 & 3.58 & - & - \\
Taranto & 53 & 9.27 & 2 & 9.43 & 118 & 2.65 & 6 \\
Crotone & 95 & 18.55 & 16 & 9.31 & 262 & 2.71 & - & - \\
\hline
\end{tabular}

a national study project on the assessment of demersal resources [5]. All the trawl surveys were carried out in autumn. A trawl net with a stretched mesh of $40 \mathrm{~mm}$ in the codend was used and the experimental hauls were carried out according to a random-stratified sampling design at depths between 10 and $800 \mathrm{~m}[30,37]$. The Scanmar Sonar System was applied on the trawl net in order to estimate the horizontal net opening during each experimental haul [39]. Abundance data were standardised to the swept surface unit [40]. Thus, density $\left(\mathrm{N} / \mathrm{km}^{2}\right)$ indices were computed for each species and survey. The following species were considered: Aristaeomorpha foliacea, Parapenaeus longirostris, and Nephrops norvegicus for crustaceans; Merluccius merluccius, Phycis blennoides, and Mullus barbatus for teleost fish. These species were chosen because they are of great commercial interest and comprise the bulk of the commercial trawl catch in the north-western Ionian fisheries. Apart from M. barbatus and, to a lesser extent, M. merluccius and P. blennoides, they are exclusively captured by trawling (Figure 4). They are also among the most studied commercial species in this Mediterranean basin. Since the recruitment of $P$. longirostris, $N$. norvegicus, $M$. merluccius, and M. barbatus occurs in the study area during autumn, the recruitment index (RI) for these species was calculated as the abundance $\left(\mathrm{N} / \mathrm{km}^{2}\right)$ of specimens younger than 1 year ( $0+$ group) $[41,42]$ collected during each survey. Although the shrimp Aristeus antennatus is one of the most abundant deep-water species in the northwestern Ionian Sea, it has not been considered in this study due to its very wide depth distribution that often makes both adult stock and recruitment less available to trawling $[43,44]$.

2.2. Data Processing. With the purpose of trying to gain insight into which combination of the environmental variables considered and fishing effort could determine the observed changes in the abundance data, multiple linear regression analyses were carried out. For each density and recruitment data set (response variables), six candidate models were evaluated. Besides the global model, we selected models that combined fishing effort with global (NAO) or regional (SST and precipitation) climatic indices, and models involving NAO or regional climatic indices, separately, as the only predictive variable fishing effort. In order to reduce the effect of extreme abundance data, these were logtransformed.

Model selection was carried out in the framework of information-theoretic approach [45], which applies Akaike's Information Criterion (AIC) to select the most parsimonious model, that is, the one that achieves the most proper trade-off between bias and variance. Considering the small size of the sample with respect to the number of estimated parameters in each model, the second-order information criterion $\left(\mathrm{AIC}_{c}\right)$ was applied and AIC differences $\left(\Delta_{i}\right)$ and Akaike weights $\left(w_{i}\right)$ were also based on $\mathrm{AIC}_{c}$ estimates. The best approximating model for each data set was selected by ranking of Akaike weights. For further comparison between the candidate models in terms of variation explained, adjusted $R^{2}$ values are also reported. Regression analyses were performed using SPSS version 18 [46].

\section{Results}

Fluctuating changes over time were observed for the density in crustacean (Figure 5(a)) and fish species (Figure 5(b)) and recruitment indices (Figure 6).

A summary of the six candidate models applied to explain the relationships between the density index and RI of each species and the environmental variables and fishing effort is reported in Tables 2(a) and 2(b), respectively. Table 3 reports the estimated regression coefficients and the relative standard errors in the models selected on the basis of ranking of $\Delta_{i} \mathrm{AIC}_{c}$.

Ranking of $\Delta_{i}$ for $A$. foliacea density data led to the selection of the model involving fishing effort and NAO as predictive variables, inversely and directly related to density indices, respectively. Comparable values of $\mathrm{AIC}_{c}$ and $w_{i}$ were also estimated for the model including the fishing effort as the only predictive variable.

For $N$. norvegicus data, the selected model highlights an inverse relationship with fishing effort and a dependence on the regional climatic factors (inversely to SST and directly to precipitation).

The best approximating model for $P$. longirostris is that including the fishing effort together with global (NAO) and regional (SST and precipitation) climatic indices. This model indicated inverse relationships between density and fishing effort and between density and SST and positive relationships between density and NAO and between density and precipitation.

The best approximating model for M. merluccius was chosen to be that consisting of a direct regression with the NAO index.

For P. blennoides density data, comparable values of $\mathrm{AIC}_{c}$ and $w_{i}$ were estimated for the model including as the only predictive variable the fishing effort (inverse) or the NAO index (direct). However, in both cases very low $R^{2}$ values were obtained. 
TABLE 2: (a) Summary of the six candidate models for density data of the species investigated in the Ionian Sea, including AIC ${ }_{c}$, $\Delta_{i}$ values for $\mathrm{AIC}_{c}$, Akaike weights $\left(w_{i}\right)$, based on $\mathrm{AIC}_{c}$, and adjusted $R^{2}$ values. Models are ordered in terms of $\Delta_{i}$ for AIC . Predictive variables are: 1: fishing effort, 2: NAO index, 3: SST and 4: precipitation. (b) Summary of the six candidate models for recruitment index of the species investigated in the Ionian Sea, including $\mathrm{AIC}_{c}, \Delta_{i}$ values for $\mathrm{AIC}_{c}$, Akaike weights $\left(w_{i}\right)$, based on $\mathrm{AIC}_{c}$, and adjusted $R^{2}$ values. Models are ordered in terms of $\Delta_{i}$ for $\mathrm{AIC}_{c}$. Predictive variables are: 1: fishing effort, 2: NAO index, 3: SST and 4: precipitation.

(a)

\begin{tabular}{|c|c|c|c|c|c|}
\hline Dependent variable & Model & $\mathrm{AlC}_{c}$ & $\Delta_{i} \mathrm{AlC}_{c}$ & $\mathrm{w}_{i}$ & Adjusted $R^{2}$ \\
\hline \multirow{6}{*}{$\begin{array}{l}\text { Density index }(\ln ) \\
\text { Aristaeomropha foliacea }\end{array}$} & $\left\{\begin{array}{ll}1 & 2\end{array}\right\}$ & 9.168 & 0.000 & 0.408 & 0.434 \\
\hline & $\{1\}$ & 9.381 & 0.213 & 0.367 & 0.397 \\
\hline & $\left\{\begin{array}{llll}1 & 2 & 3 & 4\end{array}\right\}$ & 11.728 & 2.560 & 0.113 & 0.389 \\
\hline & $\left\{\begin{array}{lll}1 & 3 & 4\end{array}\right\}$ & 12.059 & 2.891 & 0.096 & 0.352 \\
\hline & $\left\{\begin{array}{ll}3 & 4\end{array}\right\}$ & 16.315 & 7.147 & 0.011 & 0.116 \\
\hline & $\{2\}$ & 18.228 & 9.060 & 0.004 & -0.048 \\
\hline \multirow{6}{*}{$\begin{array}{l}\text { Density index Nephrops } \\
\text { norvegicus }\end{array}$} & $\left\{\begin{array}{lll}1 & 3 & 4\end{array}\right\}$ & 167.605 & 0.000 & 0.442 & 0.498 \\
\hline & $\{1\}$ & 169.025 & 1.420 & 0.217 & 0.402 \\
\hline & $\left\{\begin{array}{llll}1 & 2 & 3 & 4\end{array}\right\}$ & 169.329 & 1.724 & 0.187 & 0.465 \\
\hline & $\left\{\begin{array}{ll}1 & 2\end{array}\right\}$ & 170.446 & 2.841 & 0.107 & 0.380 \\
\hline & $\left\{\begin{array}{ll}3 & 4\end{array}\right\}$ & 172.140 & 4.535 & 0.046 & 0.316 \\
\hline & $\{2\}$ & 178.854 & 11.249 & 0.002 & -0.067 \\
\hline \multirow{6}{*}{$\begin{array}{l}\text { Density index }(\ln ) \\
\text { Parapenaeus longirostris }\end{array}$} & $\left\{\begin{array}{llll}1 & 2 & 3 & 4\end{array}\right\}$ & 5.772 & 0.000 & 0.555 & 0.235 \\
\hline & $\left\{\begin{array}{ll}1 & 2\end{array}\right\}$ & 7.776 & 2.004 & 0.204 & 0.263 \\
\hline & $\left\{\begin{array}{lll}1 & 3 & 4\end{array}\right\}$ & 8.510 & 2.738 & 0.141 & 0.171 \\
\hline & $\left\{\begin{array}{ll}3 & 4\end{array}\right\}$ & 10.470 & 4.698 & 0.053 & 0.136 \\
\hline & $\{1\}$ & 11.131 & 5.359 & 0.038 & 0.162 \\
\hline & $\{2\}$ & 13.832 & 8.060 & 0.010 & 0.017 \\
\hline \multirow{6}{*}{$\begin{array}{l}\text { Density index Merluccius } \\
\text { merluccius }\end{array}$} & $\{2\}$ & 203.555 & 0.000 & 0.454 & 0.306 \\
\hline & $\left\{\begin{array}{llll}1 & 2 & 3 & 4\end{array}\right\}$ & 204.465 & 0.910 & 0.288 & 0.357 \\
\hline & $\left\{\begin{array}{ll}1 & 2\end{array}\right\}$ & 205.453 & 1.898 & 0.176 & 0.261 \\
\hline & $\left\{\begin{array}{ll}3 & 4\end{array}\right\}$ & 208.339 & 4.784 & 0.042 & 0.125 \\
\hline & $\left\{\begin{array}{lll}1 & 3 & 4\end{array}\right\}$ & 209.139 & 5.584 & 0.028 & 0.121 \\
\hline & $\{1\}$ & 210.826 & 7.271 & 0.012 & -0.064 \\
\hline \multirow{6}{*}{$\begin{array}{l}\text { Density index Phycis } \\
\text { blennoides }\end{array}$} & $\{1\}$ & 181.760 & 0.000 & 0.329 & -0.060 \\
\hline & $\{2\}$ & 181.827 & 0.067 & 0.318 & -0.064 \\
\hline & $\left\{\begin{array}{ll}3 & 4\end{array}\right\}$ & 183.444 & 1.684 & 0.142 & -0.115 \\
\hline & $\left\{\begin{array}{ll}1 & 2\end{array}\right\}$ & 183.738 & 1.979 & 0.122 & -0.134 \\
\hline & $\left\{\begin{array}{lll}1 & 3 & 4\end{array}\right\}$ & 184.990 & 3.230 & 0.065 & -0.169 \\
\hline & $\left\{\begin{array}{llll}1 & 2 & 3 & 4\end{array}\right\}$ & 186.990 & 5.230 & 0.024 & -0.266 \\
\hline \multirow{6}{*}{$\begin{array}{l}\text { Density index }(\mathrm{ln}) \\
\text { Mullus barbatus }\end{array}$} & $\{1\}$ & -1.962 & 0.000 & 0.455 & 0.098 \\
\hline & $\left\{\begin{array}{ll}1 & 2\end{array}\right\}$ & -0.847 & 1.115 & 0.260 & 0.083 \\
\hline & $\{2\}$ & 0.610 & 2.571 & 0.126 & -0.049 \\
\hline & $\left\{\begin{array}{lll}1 & 3 & 4\end{array}\right\}$ & 1.947 & 3.909 & 0.064 & -0.035 \\
\hline & $\left\{\begin{array}{ll}3 & 4\end{array}\right\}$ & 2.121 & 4.082 & 0.059 & -0.092 \\
\hline & $\left\{\begin{array}{llll}1 & 2 & 3 & 4\end{array}\right\}$ & 3.147 & 5.109 & 0.035 & -0.070 \\
\hline
\end{tabular}

(b)

\begin{tabular}{|c|c|c|c|c|c|}
\hline Dependent variable & Model & $\mathrm{AlC}_{c}$ & $\Delta_{i} \mathrm{AlC}_{c}$ & $\mathrm{w}_{i}$ & Adjusted $R^{2}$ \\
\hline \multirow{6}{*}{$\begin{array}{l}\text { Recruitment index }(\ln ) \\
\text { Parapenaeus longirostris }\end{array}$} & $\{1\}$ & 15.095 & 0.000 & 0.447 & 0.476 \\
\hline & $\left\{\begin{array}{lll}1 & 3 & 4\end{array}\right\}$ & 16.546 & 1.451 & 0.216 & 0.480 \\
\hline & $\left\{\begin{array}{ll}1 & 2\end{array}\right\}$ & 16.653 & 1.558 & 0.205 & 0.453 \\
\hline & $\left\{\begin{array}{llll}1 & 2 & 3 & 4\end{array}\right\}$ & 17.601 & 2.506 & 0.128 & 0.467 \\
\hline & $\left\{\begin{array}{ll}3 & 4\end{array}\right\}$ & 25.136 & 10.041 & 0.003 & 0.099 \\
\hline & $\{2\}$ & 27.166 & 12.070 & 0.001 & -0.066 \\
\hline
\end{tabular}


(b) Continued.

\begin{tabular}{|c|c|c|c|c|c|}
\hline Dependent variable & Model & $\mathrm{AlC}_{c}$ & $\Delta_{i} \mathrm{AlC}_{c}$ & $\mathrm{w}_{i}$ & Adjusted $R^{2}$ \\
\hline \multirow{6}{*}{$\begin{array}{l}\text { Recruitment index } \\
\text { Nephrops norvegicus }\end{array}$} & $\left\{\begin{array}{lll}1 & 3 & 4\end{array}\right\}$ & 151.903 & 0.000 & 0.465 & 0.481 \\
\hline & $\left\{\begin{array}{llll}1 & 2 & 3 & 4\end{array}\right\}$ & 153.319 & 1.416 & 0.229 & 0.457 \\
\hline & $\{1\}$ & 154.145 & 2.242 & 0.152 & 0.350 \\
\hline & $\left\{\begin{array}{ll}3 & 4\end{array}\right\}$ & 155.191 & 3.288 & 0.090 & 0.342 \\
\hline & $\left\{\begin{array}{ll}1 & 2\end{array}\right\}$ & 155.976 & 4.073 & 0.061 & 0.311 \\
\hline & $\{2\}$ & 161.916 & 10.013 & 0.003 & -0.026 \\
\hline \multirow{6}{*}{$\begin{array}{l}\text { Recruitment index } \\
\text { Merluccius merluccius }\end{array}$} & $\{2\}$ & 184.842 & 0.000 & 0.539 & 0.293 \\
\hline & $\left\{\begin{array}{ll}1 & 2\end{array}\right\}$ & 186.792 & 1.950 & 0.203 & 0.245 \\
\hline & $\left\{\begin{array}{llll}1 & 2 & 3 & 4\end{array}\right\}$ & 187.136 & 2.294 & 0.171 & 0.290 \\
\hline & $\left\{\begin{array}{ll}3 & 4\end{array}\right\}$ & 189.820 & 4.978 & 0.045 & 0.098 \\
\hline & $\left\{\begin{array}{lll}1 & 3 & 4\end{array}\right\}$ & 191.050 & 6.208 & 0.024 & 0.072 \\
\hline & $\{1\}$ & 191.765 & 6.923 & 0.017 & -0.062 \\
\hline \multirow{6}{*}{$\begin{array}{l}\text { Recruitment index }(\ln ) \\
\text { Mullus barbatus }\end{array}$} & $\{2\}$ & 8.891 & 0.000 & 0.324 & -0.070 \\
\hline & $\{1\}$ & 9.017 & 0.126 & 0.305 & -0.079 \\
\hline & $\left\{\begin{array}{ll}3 & 4\end{array}\right\}$ & 10.371 & 1.480 & 0.155 & -0.124 \\
\hline & $\left\{\begin{array}{ll}1 & 2\end{array}\right\}$ & 10.674 & 1.783 & 0.133 & -0.149 \\
\hline & $\left\{\begin{array}{lll}1 & 3 & 4\end{array}\right\}$ & 12.355 & 3.464 & 0.057 & -0.235 \\
\hline & $\left\{\begin{array}{llll}1 & 2 & 3 & 4\end{array}\right\}$ & 13.961 & 5.070 & 0.026 & -0.335 \\
\hline
\end{tabular}

For M. barbatus, the best approximating model from ranking of $\Delta_{i}$ and $w_{i}$ was that involving the fishing effort as the only inverse predictive variable, but the value of $R^{2}$ estimated was also very low in this case.

With respect to recruitment data, the best approximating model for P. longirostris contemplates an inverse relationship with fishing effort.

For $N$. norvegicus recruits, the same dependence on fishing effort and regional climatic indices as the whole population was found.

The best approximating model for M. merluccius recruitment data testified a direct relationship with NAO.

For M. barbatus data, similar results were found for two models including only one predictive variable each (NAO and fishing effort), but both showed very low $R^{2}$ values, as in the case of the whole population.

\section{Discussion and Conclusions}

At the end of the 1980s the Ionian Sea experienced a strong modification of its water mass properties and thermohaline circulation $[9,12,14,15,18]$. The present results highlight that in the period 1985-2005 the SST in the Ionian did not show the increasing trend that characterized the Mediterranean as a whole [47]. On the contrary, at the end of the 1980s, the reversal of the Ionian gyre caused a greater input of colder and less saline Atlantic waters into this basin [18]. Only at the end of EMT did the SST values begin to match the surface waters of the whole Mediterranean [48].

All the demersal species considered in this study exhibited oscillating changes in their population and recruitment abundance.

The regime shift recorded at the end of the 1980s has had direct effects on several marine ecosystem components encompassing more trophic levels and different Mediterranean basins (see $[11,18]$, and references therein $[19,24,25$, $49,50])$. The environmental change observed in the Ionian Sea at the end of 1980s could have affected recruitment directly, through its effects on the survival rate of individuals from eggs to juveniles, or indirectly, through bottom-up effects of the changes in zooplanktonic species [51]. The fluctuations observed in the abundance indices of the whole sampled populations most probably reflect the changes in recruitment, which represent the bulk of the stock in many demersal species [8].

In this respect, even though at the end of the 1980s the abrupt changes of SST, salinity, and density as well as nutrients of the Ionian water masses together with large scale climatic drivers (NAO) could have had both direct and indirect effects on the recruitment and abundance of the demersal resources, the role played by the fishing pressure in the area seems to be important. In fact, the analysis carried out through the model selection criteria detected significant relationships between the density of some species and both climatic factors and fishing effort. In all these species an increase in their abundances was significantly related to the decrease in the working days recorded over the study period.

Although population mechanisms act in very-highdimension natural systems of great complexity which make it difficult to disentangle environmental from fishing effects as well as the nature of their interactions [52-54], there is no doubt that a decrease in the fishing pressure can favour an increase in the abundance of fish and shellfish stocks $[2,3]$. However, the effect due to the reduction of fishing varies greatly between the different species. In this respect, the effect observed in A. foliacea, $P$. longirostris, and $N$. norvegicus seems to be realistically causal. In fact, these crustacean stocks show overfishing conditions in both the 
TABLE 3: Estimated regression coefficients and relative standard errors in the models selected on the basis of $\mathrm{AIC}_{c}, \Delta_{i}$ for $\mathrm{AIC}_{c}$ and $\mathrm{Akaike}$ weights $\left(w_{i}\right)$ values. Predictive variables are: 1: fishing effort, 2: NAO index, 3: SST and 4: precipitation.

\begin{tabular}{|c|c|c|c|}
\hline Dependent variable & Predictive variable & $\beta$ & Standard error \\
\hline \multirow{3}{*}{$\begin{array}{l}\text { Density index }(\ln ) A \text {. } \\
\text { foliacea }\end{array}$} & (constant) & 13.552 & 2.293 \\
\hline & 1 & -0.035 & 0.010 \\
\hline & 2 & 0.214 & 0.154 \\
\hline \multirow{4}{*}{$\begin{array}{l}\text { Density index } N \text {. } \\
\text { norvegicus }\end{array}$} & (constant) & 2127.840 & 660.323 \\
\hline & 1 & -2.693 & 1.091 \\
\hline & 3 & -58.976 & 30.678 \\
\hline & 4 & 0.355 & 0.495 \\
\hline \multirow{5}{*}{$\begin{array}{l}\text { Density index }(\ln ) P \text {. } \\
\text { longirostris }\end{array}$} & (constant) & 16.037 & 5.567 \\
\hline & 1 & -0.015 & 0.009 \\
\hline & 2 & 0.183 & 0.126 \\
\hline & 3 & -0.253 & 0.258 \\
\hline & 4 & 0.002 & 0.004 \\
\hline Density index & (constant) & 548.557 & 93.731 \\
\hline M. merluccius & 2 & 122.402 & 43.096 \\
\hline Density index & (constant) & 369.053 & 369.330 \\
\hline P. blennoides & 1 & -0.489 & 1.572 \\
\hline Density index (ln) & (constant) & 10.631 & 1.662 \\
\hline M. barbatus & 1 & -0.012 & 0.007 \\
\hline Recruitment index (ln) & (constant) & 16.073 & 2.745 \\
\hline P. longirostris & 1 & -0.046 & 0.012 \\
\hline \multirow{4}{*}{$\begin{array}{l}\text { Recruitment index } N \text {. } \\
\text { norvegicus }\end{array}$} & (constant) & 1434.513 & 416.091 \\
\hline & 1 & -1.497 & 0.687 \\
\hline & 3 & -45.165 & 19.331 \\
\hline & 4 & 0.036 & 0.312 \\
\hline Recruitment index & (constant) & 232.864 & 54.057 \\
\hline M. merluccius & 2 & 68.711 & 24.855 \\
\hline Recruitment index $(\ln )$ & (constant) & 6.916 & 0.352 \\
\hline M. barbatus & 2 & -0.058 & 0.148 \\
\hline
\end{tabular}

Ionian Sea [30, 37, 55-58] and Italian waters [7]. Due to the high vulnerability to trawling of both adults and juveniles in all three species, a reduction in the working days of this type of fishing could reliably favour stock recovery and, thus, an abundance increase. However, Capezzuto et al. [59] revealed that the increase in the abundance of $A$. foliacea verified mostly in the period 2000-2004 correlated significantly with the increase in temperature and salinity detected from 1995 to 2005 between 200 and $800 \mathrm{~m}$ in the Ionian Sea. This fact can be explained according to Ghidalia and Bourgois [60] and Bombace [61] by a hydrological hypothesis: $A$. foliacea is preferentially distributed in warmer and high-salinity waters. Temperature and salinity between 200 and $800 \mathrm{~m}$ were not considered in the present work.

In $N$. norvegicus an inverse relationship between density and both fishing effort and SST was detected while a direct relationship with precipitation came out. With reference to the first driver, since the catch of Norway lobster in the Ionian Sea mostly consists of juveniles [58], this relationship also seems to be realistic for recruitment. In respect to the SST, although the influence of the temperature on the recruitment has also been proved for other Mediterranean demersal species $[62,63]$, probably temperature alone cannot explain the change in the $N$. norvegicus abundance observed in the Ionian Sea. Maynou and Sardà [64] found significant relationships between the catch rate of this crustacean and some environmental factors, such as atmospheric pressure, cloud cover, and sea-weather conditions. The precipitation effect detected in this work could be related to cloud cover observed by Maynou and Sardà [64]. These authors hypothesized that the light intensity reaching the seabed has a primary influence on the activity rates of $N$. norvegicus and thus on its vulnerability to trawling. Ungaro and Gramolini [65] found a possible influence of the water temperature at sea bottoms on the spatial distribution of $P$. longirostris in the southern Adriatic. However, these authors, in agreement with Abelló et al. [66], reported that spatial differences in abundance could also be due to the fishery exploitation. Recently, Ligas et al. [67] reported an increasing trend of $P$. longirostris abundance correlated to a rise in SST, a corresponding decrease of wind circulation and to the reduction of fishing effort. 


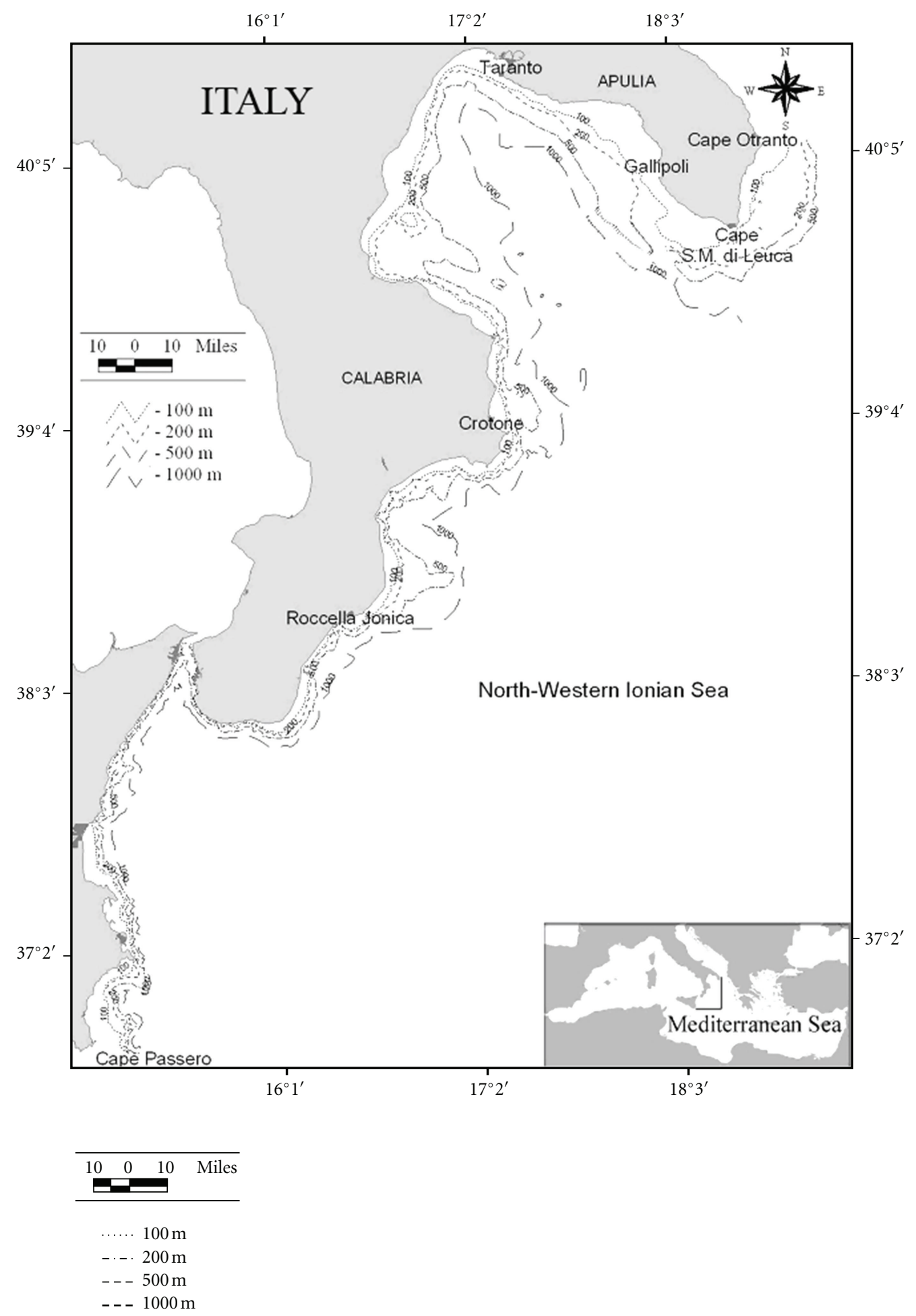

FIgURE 1: Map of the study area.

In M. merluccius, both for the whole sampled population and recruits, a positive relationship with the NAO index was detected. The existence of positive relationships between ecological processes in the sea and NAO was observed in many studies, even though the underlying mechanisms often remain unexplained ([18, and references therein],
$[19$, and references therein] [51, 68-70]). The changes in environmental factors (atmospheric pressure, temperature, wind, precipitation, etc.) linked to the NAO can cause deep modifications to the ecosystem influencing, both directly and indirectly, individual organisms and populations as well as interspecies relationships and trophic webs $[51,70,71]$. 

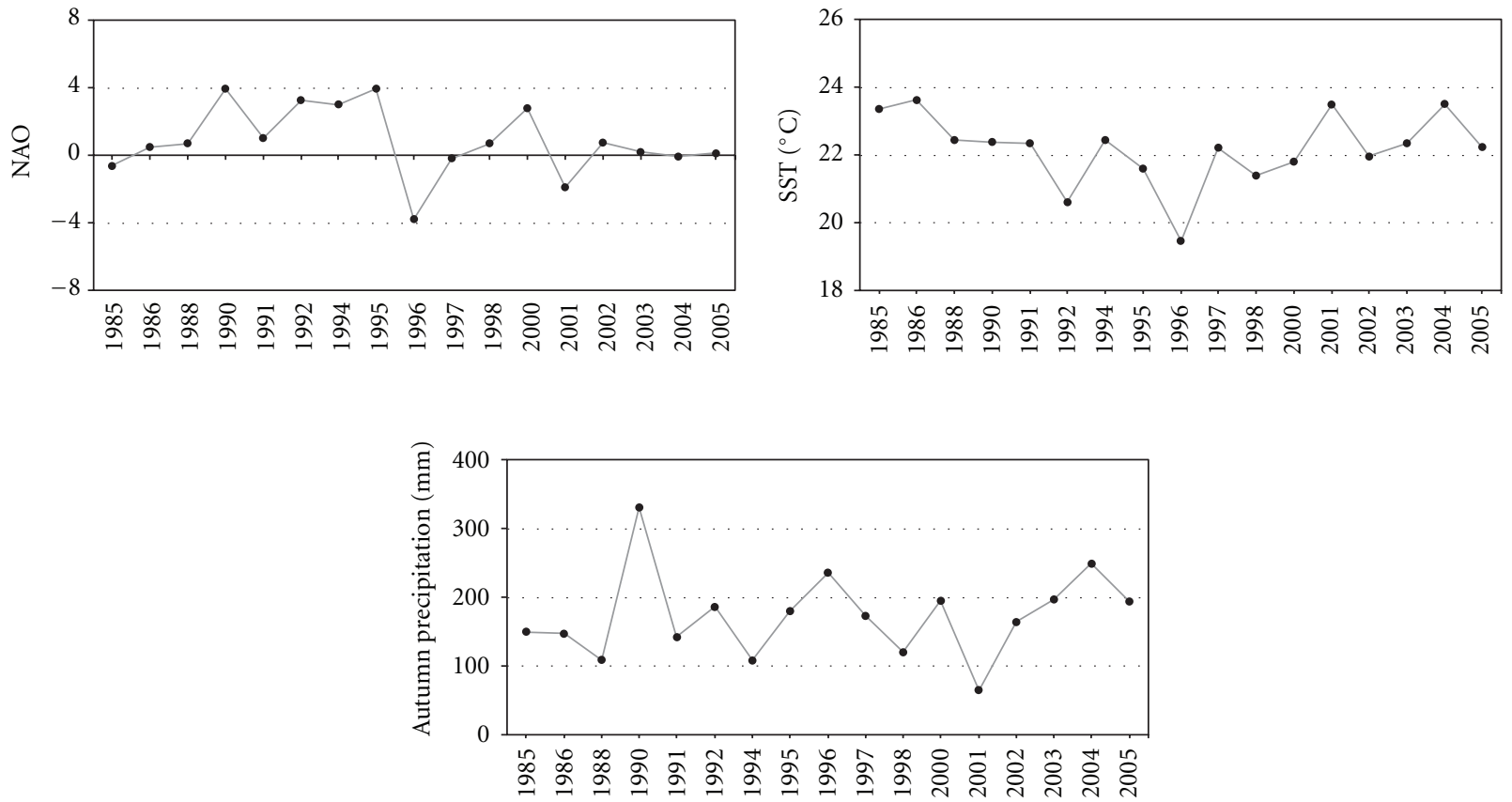

FIgURE 2: NAO index and Sea Surface Temperature (SST) and autumn precipitation recorded in the period 1985-2005 for the north-western Ionian Sea.

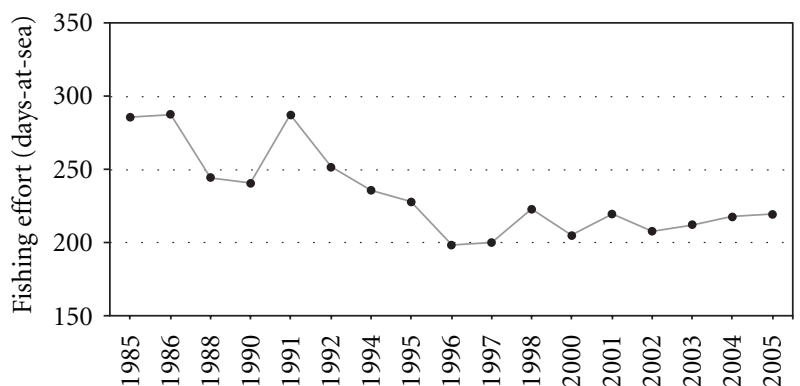

FIGURE 3: Fishing effort expressed in terms of the number of workdays in the north-western Ionian Sea from 1985 to 2005.

The effects at the first levels of the trophic chain, that is on very short-lived species, are probably easier to identify ([18, and references therein] $[25,68]$ ) while those on fish and other high-trophic level organisms are far from being well understood. In the Mediterranean, Lloret et al. [72] reported that the recruitment of continental shelf species, among which, E. cirrhosa, M. merluccius, and M. poutassou, was positively correlated with the river run-off and/or wind mixing index. Orsi Relini et al. [73] found a positive relationship between the summer biomass of E. cirrhosa and winter NAO index. A direct influence of NAO on the water mass circulation and consequent effects on distribution of M. merluccius was established by Abella et al. [74] from the Tyrrhenian to Ligurian Sea and on distribution of $M$. merluccius and Aristeus antennatus by Massutí et al. [75] off the Balearic Islands.

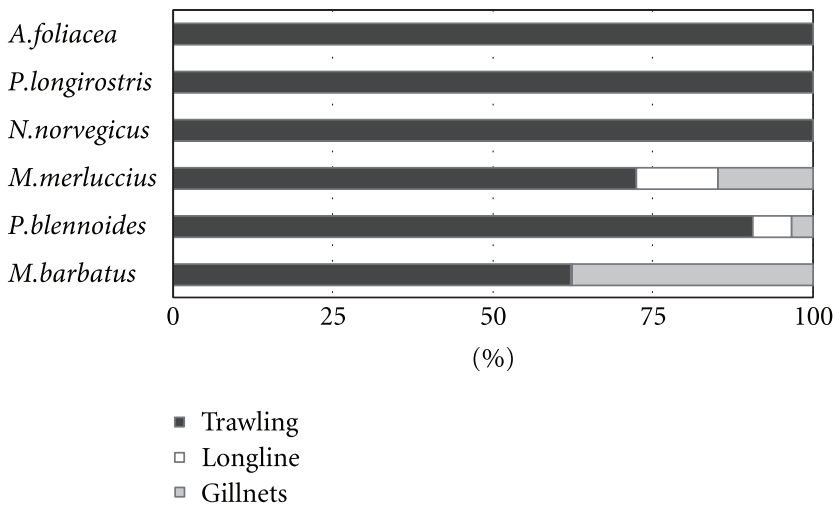

Figure 4: Percentage of commercial catches in some demersal species obtained with different gears in the north-western Ionian Sea.

Maynou [76] found a positive correlation between the average annual NAO index and the annual catches of the shrimp Aristeus antennatus in six ports along the Catalonia coast. This author hypothesized that the NAOinduced environmental variability could favour secondary production enhancing the food supply for $A$. antennatus. The greater food availability for this shrimp would strengthen the reproductive potential of a particular year class resulting in increased catches 1 to 3 years later.

A similar hypothesis could also be suggested for hake in the Ionian Sea in agreement with the fact that the changes during 1987-1988 affected the features of the plankton communities. Indeed, an enrichment of the epipelagic system, in terms of chlorophyll $a$ concentrations, primary production rates, ciliate abundance and zooplankton biomass, was 

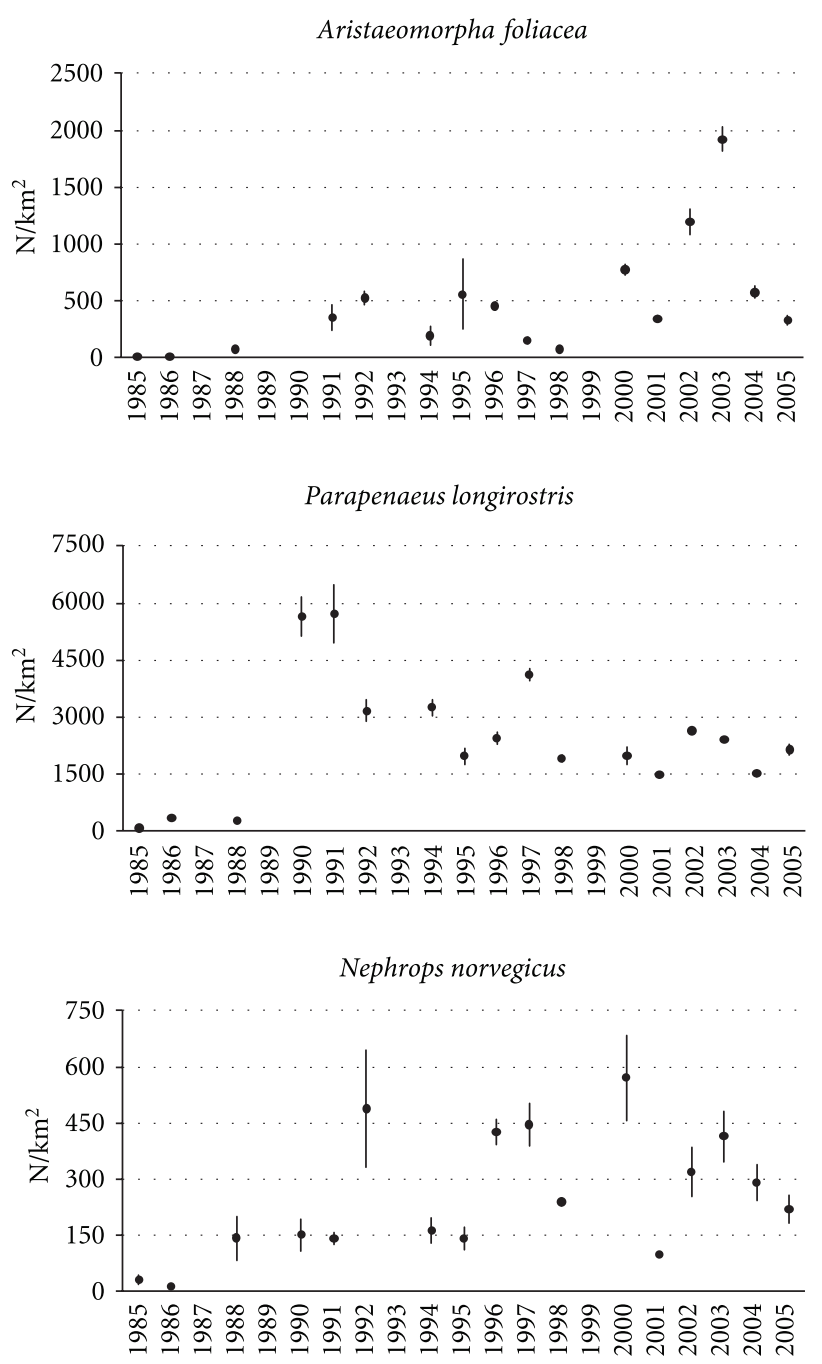

(a)
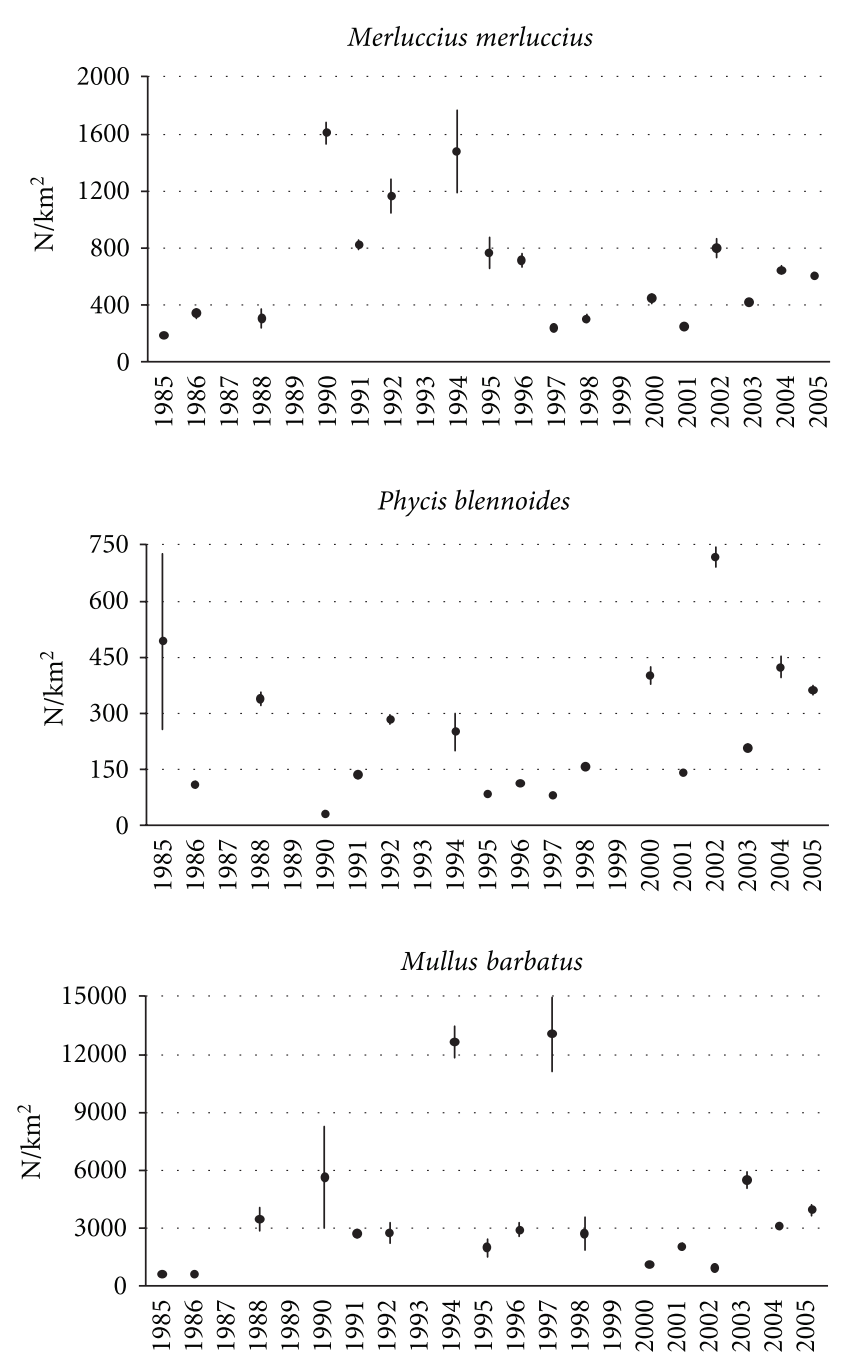

(b)

FIgURE 5: (a) Density indices with standard deviation in crustacean species caught from 1985 to 2005 in the north-western Ionian Sea. (b) Density indices with standard deviation in fish species caught from 1985 to 2005 in the north-western Ionian Sea.

detected during the years of cyclonic circulation of the water masses along the north-western Ionian coasts [18, 21-24]. Hakes feed actively in neritic water during their yearly life stages and the higher abundance of their potential prey can favour the recruitment success according to the "matchmismatch hypothesis" [1]. The marked increase in density observed in this fish during 1990 can be considered a consequence of successful recruitment. Nursery areas of this species have been identified along the north-western Ionian Sea $[41,42]$. Thus, the period of higher food availability, indirectly related to positive NAO index, would lead to enhancement of the recruitment in M. merluccius. The remarkable presence of juveniles in the catches of hake plays more in favour of environmental factors than fishing pressure as main cause of their abundance increase.

In the stock of $M$. barbatus of the Strait of Sicily it was shown that, for a given spawning stock level, higher recruitment levels correspond to positive SST anomalies [62]. In the stock of M. barbatus in the Ionian Sea the fishing effort and NAO index seem to play a comparable role on its abundance changes. The same was detected for P. blennoides. However, the very low $R^{2}$ values estimated in the models for these two fishes would indicate that the set of explanatory variables selected does not completely explain the variance in the abundance data of these species. In fact, mostly for $M$. barbatus, the abundance in the Ionian Sea could also be affected by small vessels mostly working with gillnets the effort of which has not been considered in the present work.

In conclusion, apart from hake abundance and recruitment data, for which a clear positive relationship was detected with the NAO index alone, the changes observed in the other species appear to be an interaction between bottom-up effects linked to changes in physical environment and top-down ones due to fishing. In agreement with Gislason et al. [77], the effects of fishing seem to manifest themselves within a background of natural environmental variations that are the major agent of change in the system. Analyzing the changes in different species, in contrasting 

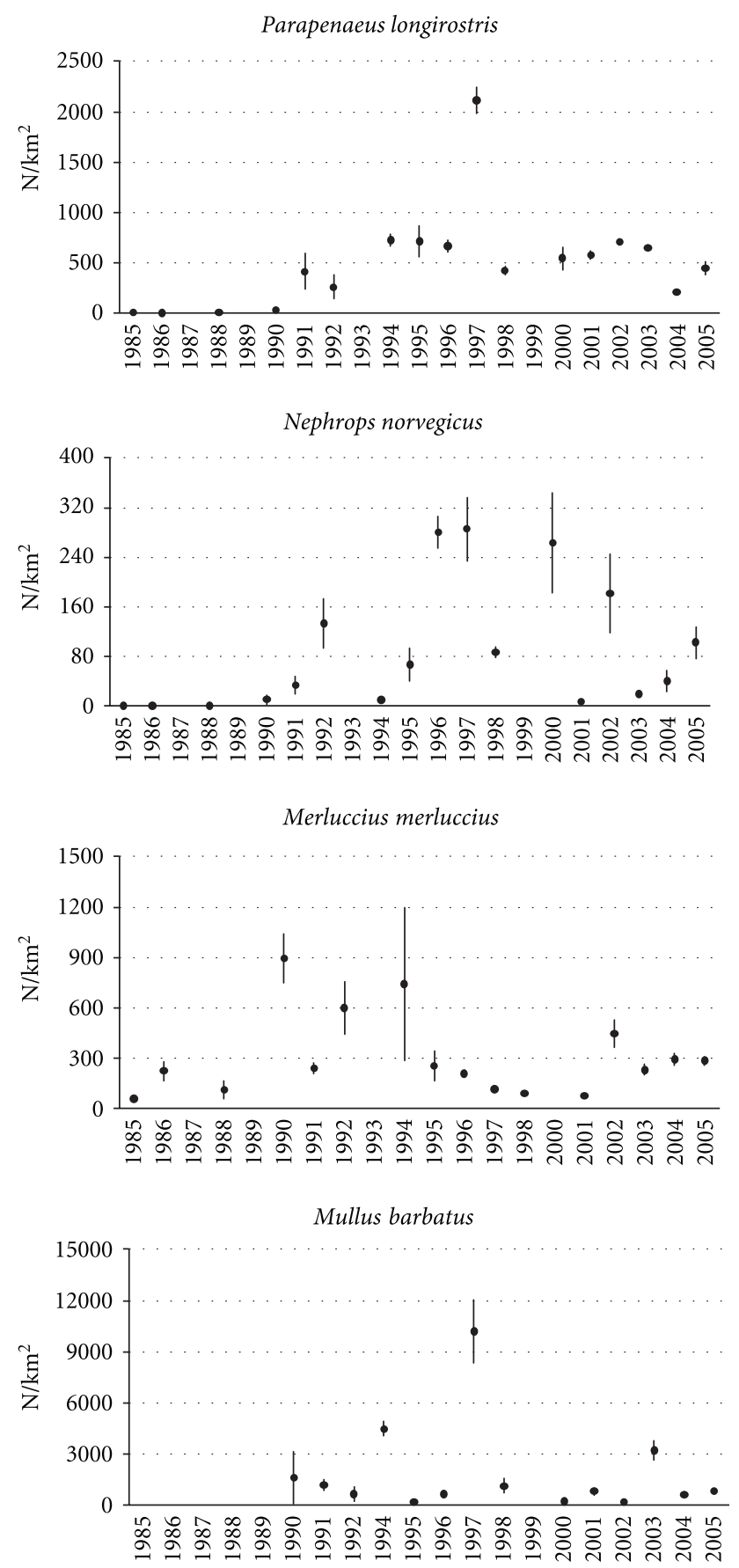

Figure 6: Recruitment indices $\left(\mathrm{N} / \mathrm{km}^{2}\right)$ with standard deviation of demersal species caught from 1985 to 2005 in the north-western Ionian Sea.

environments and subject to different fishing pressures, is expected to shed light on the relative effects of these factors and the way they interact [78].

\section{Acknowledgments}

This study benefited from data collected during the trawl surveys financed by the Italian Government (MiPAAF) as part of the programme "Assessment of Demersal Resources." Statistical analyses were supported by a grant to the University of Bari (Local Research Unit CoNISMa) as part of the VECTOR project (vector.conismamibi.it).

\section{References}

[1] D. H. Cushing, Climate and Fisheries, Academic Press, London, UK, 1982.

[2] R. L. Haedrich and S. M. Barnes, "Changes over time of the size structure in an exploited shelf fish community," Fisheries Research, vol. 31, no. 3, pp. 229-239, 1997.

[3] S. J. Hall, The effects of Fishing on Marine Ecosystems and Communities, Fish Biology and Aquatic Resources, Series 1, Blackwell Sciences, 1999.

[4] P. A. Larkin, "Concepts and issues in marine ecosystem management," Reviews in Fish Biology and Fisheries, vol. 6, no. 2, pp. 139-164, 1996.

[5] G. Relini, "Valutazione delle risorse demersali," Biologia Marina Mediterranea, vol. 5, supplement 3, pp. 3-19, 1998.

[6] J. A. Bertrand, L. Gil de Sola, C. Papaconstantinou, G. Relini, and A. Souplet, "An international bottom trawl survey in the Mediterranean: The MEDITS programme," IFREMER Actes de Colloques, vol. 26, pp. 76-93, 2002.

[7] G. Relini, J. Bertrand, and A. Zamboni, "Synthesis of the knowledge on bottom fishery resources in Central Mediterranean, Italy and Corsica," Biologia Marina Mediterranea, vol. 6, supplement 1, p. 868, 1999.

[8] J. Lleonart and F. Maynou, "Fish stock assessments in the Mediterranean: state of the art," Scientia Marina, vol. 67, no. 1, pp. 37-49, 2003.

[9] CIESM, "The Eastern Mediterranean climatic transient, its origin, evolution and impact on the ecosystem," CIESM Workshop Monographs, vol. 10, p. 88, 2000.

[10] CIESM, "Tracking long-term hydrological change in the Mediterranean Sea," CIESM Workshop Monographs, vol. 16, p. $134,2002$.

[11] CIESM, "Climate warming and related changes in Mediterranean marine biota," CIESM Workshop Monographs, vol. 35, p. 152,2008 .

[12] B. Klein, W. Roether, B. B. Manca et al., "The large deep water transient in the Eastern Mediterranean," Deep-Sea Research I, vol. 46, no. 3, pp. 371-414, 1999.

[13] A. Lascaratos, W. Roether, K. Nittis, and B. Klein, "Recent changes in deep water formation and spreading in the Eastern Mediterranean Sea: a review," Progress in Oceanography, vol. 44, no. 1-3, pp. 5-36, 1999.

[14] P. Malanotte-Rizzoli, B. B. Manca, M. R. D’Alcala et al., "The Eastern Mediterranean in the 80s and in the 90s: the big transition in the intermediate and deep circulations," Dynamics of Atmospheres and Oceans, vol. 29, no. 2-4, pp. 365395, 1999.

[15] B. B. Manca, L. Ursella, and P. Scarazzato, "New development of eastern mediterranean circulation based on hydrological observations and current measurements," Marine Ecology, vol. 23, supplement 1, pp. 237-257, 2002.

[16] G. L. E. Borzelli, M. Gačičc, V. Cardin, and G. Civitarese, "Eastern mediterranean transient and reversal of the Ionian Sea circulation," Geophysical Research Letters, vol. 36, no. 15, Article ID L15108, 2009.

[17] M. Gačić, G. L. Eusebi Borzelli, G. Civitarese, V. Cardin, and S. Yairi, "Can internal processes sustain reversals of the 
ocean upper circulation? The Ionian Sea example," Geophysical Research Letters, vol. 37, no. 9, pp. 1-5, 2010.

[18] G. Civitarese, M. Gačić, M. Lipizer, and G. L. Eusebi Borzelli, "On the impact of the Bimodal Oscillating System (BiOS) on the biogeochemistry and biology of the Adriatic and Ionian Seas (Eastern Mediterranean)," Biogeosciences, vol. 7, no. 12, pp. 3987-3997, 2010.

[19] A. Conversi, S. F. Umani, T. Peluso, J. C. Molinero, A. Santojanni, and M. Edwards, "The mediterranean sea regime shift at the end of the 1980s, and intriguing parallelisms with other european basins," PLoS One, vol. 5, no. 5, Article ID e10633, 2010.

[20] I. Vilibić, S. Matijević, and J. Šepić, "Changes in the Adriatic oceanographic properties induced by the Eastern Mediterranean Transient," Biogeosciences Discussions, vol. 9, pp. 927956, 2012.

[21] R. Casotti, A. Landolfi, C. Brunet et al., "Composition and dynamics of the phytoplankton of the Ionian Sea (eastern Mediterranean)," Journal of Geophysical Research C, vol. 108, no. 9, 19 pages, 2003.

[22] F. D'Ortenzio, M. Ragni, S. Marullo, and M. Ribera d'Alcalà, "Did biological activity in the Ionian Sea change after the Eastern Mediterranean Transient? Results from the analysis of remote sensing observations," Journal of Geophysical Research C, vol. 108, no. 9, 20 pages, 2003.

[23] R. Koppelmann and H. Weikrt, "Deep-sea zooplankton ecology of the Eastern Mediterranean State-of-the-art and perspective," CIESM Monographs, vol. 23, pp. 47-53, 2003.

[24] M. G. Mazzocchi, D. Nervegna, G. D’Elia, I. Di Capua, L. Aguzzi, and A. Boldrin, "Spring mesozooplankton communities in the epipelagic Ionian Sea in relation to the Eastern Mediterranean Transient," Journal of Geophysical Research C, vol. 108, no. 9, pp. 1-12, 2003.

[25] A. Conversi, T. Peluso, and S. Fonda-Umani, "Gulf of Trieste: a changing ecosystem," Journal of Geophysical Research C, vol. 114, no. 7, Article ID C03S90, 2009.

[26] C. N. Bianchi, "Biodiversity issues for the forthcoming tropical Mediterranean Sea," Hydrobiologia, vol. 580, no. 1, pp. 7-21, 2007.

[27] A. Tursi, G. D’Onghia, and A. Matarrese, "Firs finding of Sphoeroides pachygaster (Müller \& Troshel, 1848) in the Ionian Sea (Middle-Eastern Mediterranean)," Cybium, vol. 16, pp. 171-172, 1992.

[28] F. Mastrototaro, R. Carlucci, F. Capezzuto, and L. Sion, "First record of dwarf flathead Elates ransonnetii (Platycephalidae) in the Mediterranean Sea (North-Western Ionian Sea)," Cybium, vol. 31, no. 3, pp. 393-394, 2007.

[29] L. Sion, D. Battista, F. Mastrototaro, and R. Carlucci, "New findings of pignosed arrowtooth eel Dysomma brevirostre (Synaphobranchidae) in the Western Ionian Sea (Mediterranean Sea)," Cybium, vol. 32, no. 2, pp. 189-190, 2008.

[30] P. Maiorano, L. Sion, R. Carlucci et al., "The demersal faunal assemblage of the north-western Ionian Sea (central Mediterranean): current knowledge and perspectives," Chemistry and Ecology, vol. 26, (suppl), pp. 219-240, 2010.

[31] D. H. Gushing and R. R. Dickson, "The biological response in the sea to climate changes," Advances in Marine Biology, vol. 14, pp. 1-122, 1977.

[32] C. C. Coutant, "Compilation of temperature preference data," Journal of the Fisheries Research, Board of Canada, vol. 34, pp. 739-745, 1977.

[33] B. J. Rothschild, Dynamics of Marine Fish Populations, Harvard University Press, Cambridge, Mass, USA, 1986.
[34] A. J. Southward, G. T. Boalch, and L. Maddock, "Fluctuations in the herring and pilchard fisheries of Devon and Cornwall linked to change in climate since the 16th century," Journal of Marine Biological Association of the the United Kingdom, vol. 68, no. 3, pp. 423-445, 1988.

[35] C. Ravier and J. M. Fromentin, "Are the long-term fluctuations in Atlantic bluefin tuna (Thunnus thynnus) population related to environmental changes?" Fisheries Oceanography, vol. 13, no. 3, pp. 145-160, 2004.

[36] T. Brunel and J. Boucher, "Long-term trends in fish recruitment in the north-east Atlantic related to climate change," Fisheries Oceanography, vol. 16, no. 4, pp. 336-349, 2007.

[37] A. Tursi, A. Matarrese, G. D’Onghia, P. Maiorano, and M. Panza, "Sintesi delle ricerche sulle risorse demersali del Mar Ionio (da Capo d'Otranto a Capo Passero) realizzate nel periodo 1985-1997," Biologia Marina Mediterranea, vol. 5, supplement 3, pp. 120-129, 1998.

[38] S. P. R. Greenstreet, F. B. Spence, A. M. Shanks, and J. A. McMillan, "Fishing effects in northeast Atlantic shelf seas: patterns in fishing effort, diversity and community structure. II. Trends in fishing effort in the North Sea by UK registered vessels landing in Scotland," Fisheries Research, vol. 40, no. 2, pp. 107-124, 1999.

[39] L. Fiorentini, G. Cosimi, A. Sala, and V. Palumbo, "Caratteristiche e prestazioni delle attrezzature a strascico impiegate per la valutazione delle risorse demersali in Italia," Biologia Marina Mediterranea, vol. 1, supplement 2, pp. 115-134, 1994.

[40] D. Pauly, "Some simple methods for the assessment of tropical fish stocks," FAO Fisheries Technical Paper, 1983.

[41] R. Carlucci, G. Lembo, P. Maiorano et al., "Nursery areas of red mullet (Mullus barbatus), hake (Merluccius merluccius) and deep-water rose shrimp (Parapenaeus longirostris) in the Eastern-Central Mediterranean Sea," Estuarine, Coastal and Shelf Science, vol. 83, no. 4, pp. 529-538, 2009.

[42] M. Murenu, A. Cau, F. Colloca et al., "Mapping the potential locations of the European hake (Merluccius merluccius) nurseries in the Italian waters," in GIS/Spatial Analyses in Fishery and Aquatic Sciences, T. Nishida, P. J. Kailola, and C. E. Hollingworth, Eds., vol. 4, FAO, 2010.

[43] F. Sardà, G. D’Onghia, C. Y. Politou, J. B. Company, P. Maiorano, and K. Kapiris, "Deep-sea distribution, biological and ecological aspects of Aristeus antennatus (Risso, 1816) in the western and central Mediterranean Sea," Scientia Marina, vol. 68, no. 3, pp. 117-127, 2004.

[44] G. D’Onghia, P. Maiorano, F. Capezzuto et al., "Further evidences of deep-sea recruitment of Aristeus antennatus (Crustacea: Decapoda) and its role in the population renewal on the exploited bottoms of the Mediterranean," Fisheries Research, vol. 95, no. 2-3, pp. 236-245, 2009.

[45] K. P. Burnham and D. R. Anderson, Model Selection and Multimodel Inference: A Practical Information-Theoretic Approach, Springer, New York, NY, USA, 2nd edition, 2002.

[46] SPSS Inc., PASW Statistics Base 18, SPSS Inc., Chicago, Ill, USA, 2009.

[47] B. BuongiornoNardelli, R. Santoleri, S. Marullo, and M. Guarracino, "La temperatura superficiale del Mar Mediterraneo negli ultimi 21 anni: analisi delle misure satellitari. Clima e cambiamenti climatici," Le attività del CNR, pp. 345-348, 2007.

[48] B. B. Manca, V. Ibello, M. Pacciaroni, P. Scarazzato, and A. Giorgetti, "Ventilation of deep waters in the Adriatic and Ionian Seas following changes in thermohaline circulation of the Eastern Mediterranean," Climate Research, vol. 31, no. 2-3, pp. 239-256, 2006. 
[49] J. C. Molinero, F. Ibanez, P. Nival, E. Buecher, and S. Souissi, "North Atlantic climate and northwestern Mediterranean plankton variability," Limnology and Oceanography, vol. 50, no. 4, pp. 1213-1220, 2005.

[50] A. Santojanni, E. Arneri, V. Bernardini, N. Cingolani, M. Di Marco, and A. Russo, "Effects of environmental variables on recruitment of anchovy in the Adriatic Sea," Climate Research, vol. 31, no. 2-3, pp. 181-193, 2006.

[51] N. C. Stenseth, G. Ottersen, J. W. Hurrell, and A. Belgrano, Marine Ecosystem and Climate Variation, Oxford University Press, 2004.

[52] B. E. Skud, "Dominance in fishes: the relation between environment and abundance," Science, vol. 216, no. 4542, pp. 144-149, 1982.

[53] C. M. Duarte and J. N. Cebrian Marba, "Uncertainty of detecting sea change," Nature, vol. 356, no. 6366, p. 190, 1992.

[54] S. I. Rogers, D. Maxwell, A. D. Rijnsdorp, U. Damm, and W. Vanhee, "Fishing effects in northeast Atlantic shelf seas: patterns in fishing effort, diversity and community structure. IV. Can comparisons of species diversity be used to assess human impacts on demersal fish faunas?" Fisheries Research, vol. 40, no. 2, pp. 135-152, 1999.

[55] G. D’Onghia, P. Maiorano, A. Matarrese, and A. Tursi, “Distribution, biology, and population dynamics of Aristaeomorpha foliacea (Risso, 1827) (Decapoda, Natantia, Aristeidae) in the north-western Ionian Sea (Mediterranean Sea)," Crustaceana, vol. 71, no. 5, pp. 518-544, 1998.

[56] G. D’Onghia, A. Matarrese, P. Maiorano, and F. Perri, "Valutazione di Parapenaeus longirostris (Lucas, 1846) (Crustacea, Decapoda) nel Mar Ionio," Biologia Marina Mediterranea, vol. 5, supplement 2, pp. 273-283, 1998.

[57] R. Carlucci, G. D’Onghia, L. Sion, P. Maiorano, and A. Tursi, "Selectivity parameters and size at first maturity in deep-water shrimps, Aristaeomorpha foliacea (Risso, 1827) and Aristeus antennatus (Risso, 1816), from the North-Western Ionian Sea (Mediterranean Sea)," Hydrobiologia, vol. 557, no. 1, pp. 145154, 2006.

[58] F. Capezzuto, R. Carlucci, P. Maiorano et al., "Distribuzione spazio-temporale del reclutamento di Nephrops norvegicus (LINNAEUS, 1758) nel Mar Ionio," Biologia Marina Mediterranea, vol. 16, supplement 1, pp. 190-193, 2009.

[59] F. Capezzuto, R. Carlucci, P. Maiorano et al., "The bathyal benthopelagic fauna in the NW Ionian Sea: structure, patterns and interactions," Chemistry and Ecology, vol. 26, (suppl), pp. 199-217, 2010.

[60] W. Ghidalia and F. Bourgois, "Influence de la temperature et de l'éclairement sur la distribution des crevettes des moyennes et grandes profondeurs," Stud. Rev. General Fisheries Council for the Mediterranean, FAO, vol. 16, pp. 1-53, 1961.

[61] G. Bombace, "Considerazioni sulla distribuzione delle popolazioni di livello batiale con particolare riferimento a quelle bentonectoniche," Pubblicazioni della Stazione Zoologica di Napoli, vol. 39, pp. 7-21, 1975.

[62] D. Levi, M. G. Andreoli, A. Bonanno et al., "Embedding sea surface temperature anomalies into the stock recruitment relationship of red mullet (Mullus barbatus L. 1758) in the Strait of Sicily," Scientia Marina, vol. 67, supplement 1, pp. 259-268, 2003.

[63] V. Bartolino, F. Colloca, P. Sartor, and G. Ardizzone, "Modelling recruitment dynamics of hake, Merluccius merluccius, in the central Mediterranean in relation to key environmental variables," Fisheries Research, vol. 92, no. 2-3, pp. 277-288, 2008.
[64] F. Maynou and F. Sardà, "Influence of environmental factors on commercial trawl catches of Nephrops norvegicus (L.)," ICES Journal of Marine Science, vol. 58, no. 6, pp. 1318-1325, 2001.

[65] N. Ungaro and R. Gramolini, "Possible effect of Bottom Temperature on Distribution of Parapenaeus longirostris (Lucas, 1846) in the Southern Adriatic (Mediterranean Sea)," Turkish Journal of Fisheries and Aquatic Sciences, vol. 6, pp. 109-116, 2006.

[66] P. Abelló, A. Abella, A. Adamidou, S. Jukic-Peladic, P. Maiorano, and M. T. Spedicato, "Geographical patterns in abundance and population structure of Nephrops norvegicus and Parapenaeus longirostris (Crustacea: Decapoda) along the European Mediterranean coasts," Scientia Marina, vol. 66, no. 2, pp. 125-141, 2002.

[67] A. Ligas, S. De Ranieri, D. Micheli et al., "Analysis of the landings and trawl survey time series from the Tyrrhenian Sea (NW Mediterranean)," Fisheries Research, vol. 105, no. 1, pp. 46-56, 2010.

[68] J. M. Fromentin and B. Planque, "Calanus and environment in the eastern North Atlantic. II. Influence of the North Atlantic Oscillation on C. finmarchicus and C. helgolandicus," Marine Ecology Progress Series, vol. 134, no. 1-3, pp. 111-118, 1996.

[69] G. Ottersen and N. C. Stenseth, "Atlantic climate governs oceanographic and ecological variability in the Barents Sea," Limnology and Oceanography, vol. 46, no. 7, pp. 1774-1780, 2001.

[70] N. C. Stenseth, A. Mysterud, G. Ottersen, J. W. Hurrell, K. S. Chan, and M. Lima, "Ecological effects of climate fluctuations," Science, vol. 297, no. 5585, pp. 1292-1296, 2002.

[71] K. F. Drinkwater, "The response of Atlantic cod (Gadus morhua) to future climate change," ICES Journal of Marine Science, vol. 62, no. 7, pp. 1327-1337, 2005.

[72] J. Lloret, J. Lleonart, I. Solé, and J. M. Fromentin, "Fluctuations of landings and environmental conditions in the northwestern Mediterranean sea," Fisheries Oceanography, vol. 10, no. 1, pp. 33-50, 2001.

[73] L. Orsi Relini, A. Mannini, F. Fiorentino, G. Palandri, and G. Relini, "Biology and fishery of Eledone cirrhosa in the Ligurian Sea," Fisheries Research, vol. 78, no. 1, pp. 72-88, 2006.

[74] A. Abella, F. Fiorentino, A. Mannini, and L. Orsi Relini, "Exploring relationships between recruitment of European hake (Merluccius merluccius L. 1758) and environmental factors in the Ligurian Sea and the Strait of Sicily (Central Mediterranean)," Journal of Marine Systems, vol. 71, no. 3-4, pp. 279-293, 2008.

[75] E. Massutí, S. Monserrat, P. Oliver et al., "The influence of oceanographic scenarios on the population dynamics of demersal resources in the western Mediterranean: hypothesis for hake and red shrimp off Balearic Islands," Journal of Marine Systems, vol. 71, no. 3-4, pp. 421-438, 2008.

[76] F. Maynou, "Environmental causes of the fluctuations of red shrimp (Aristeus antennatus) landings in the Catalan Sea," Journal of Marine Systems, vol. 71, no. 3-4, pp. 294-302, 2008.

[77] H. Gislason, M. Sinclair, K. Sainsbury, and R. O’boyle, "Symposium overview: incorporating ecosystem objectives within fisheries management," ICES Journal of Marine Science, vol. 57, no. 3, pp. 468-475, 2000.

[78] T. Rouyer, J. M. Fromentin, F. Ménard et al., "Complex interplays among population dynamics, environmental forcing, and exploitation in fisheries," Proceedings of the National Academy of Sciences of the United States of America, vol. 105, no. 14, pp. 5420-5425, 2008. 

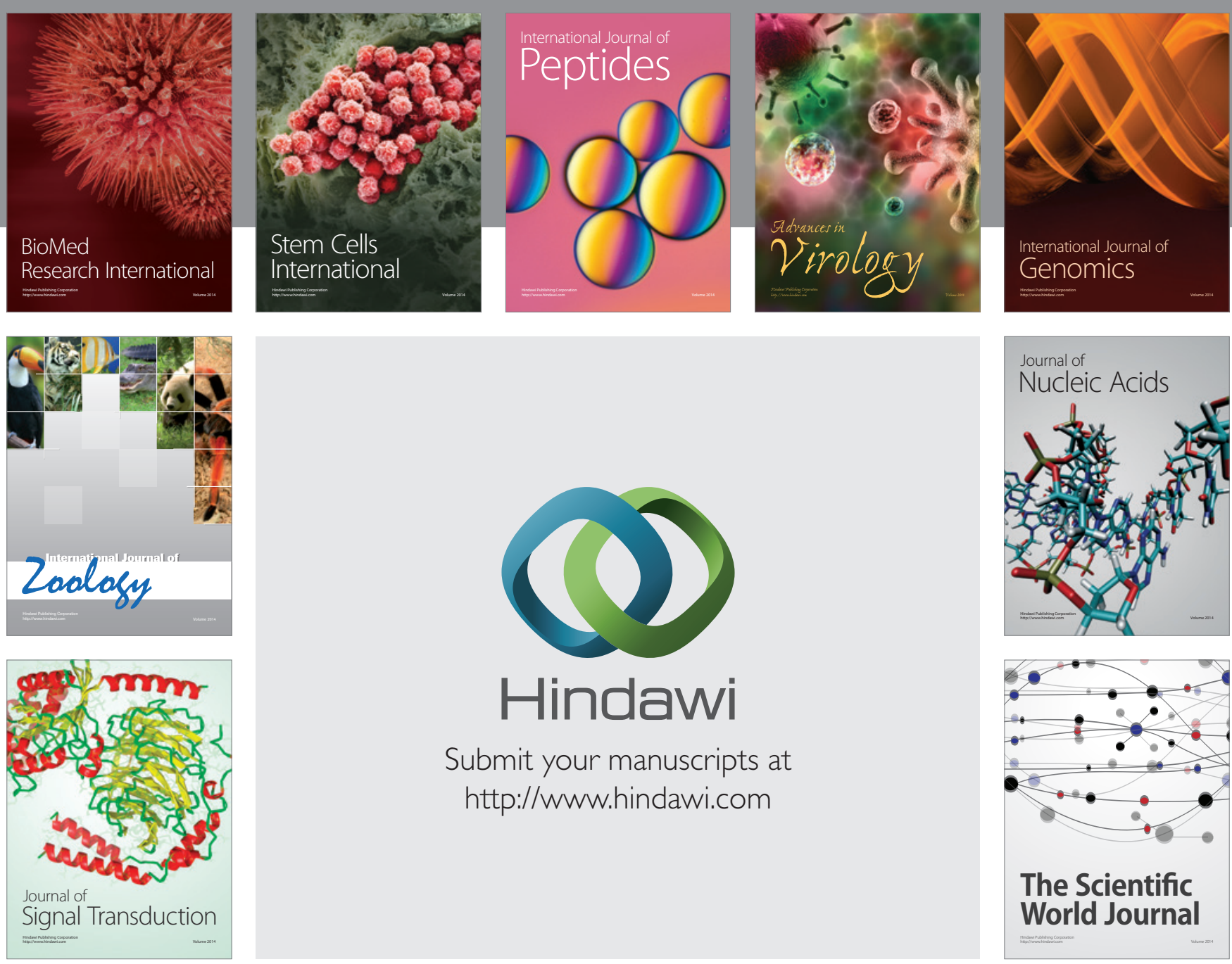

Submit your manuscripts at

http://www.hindawi.com
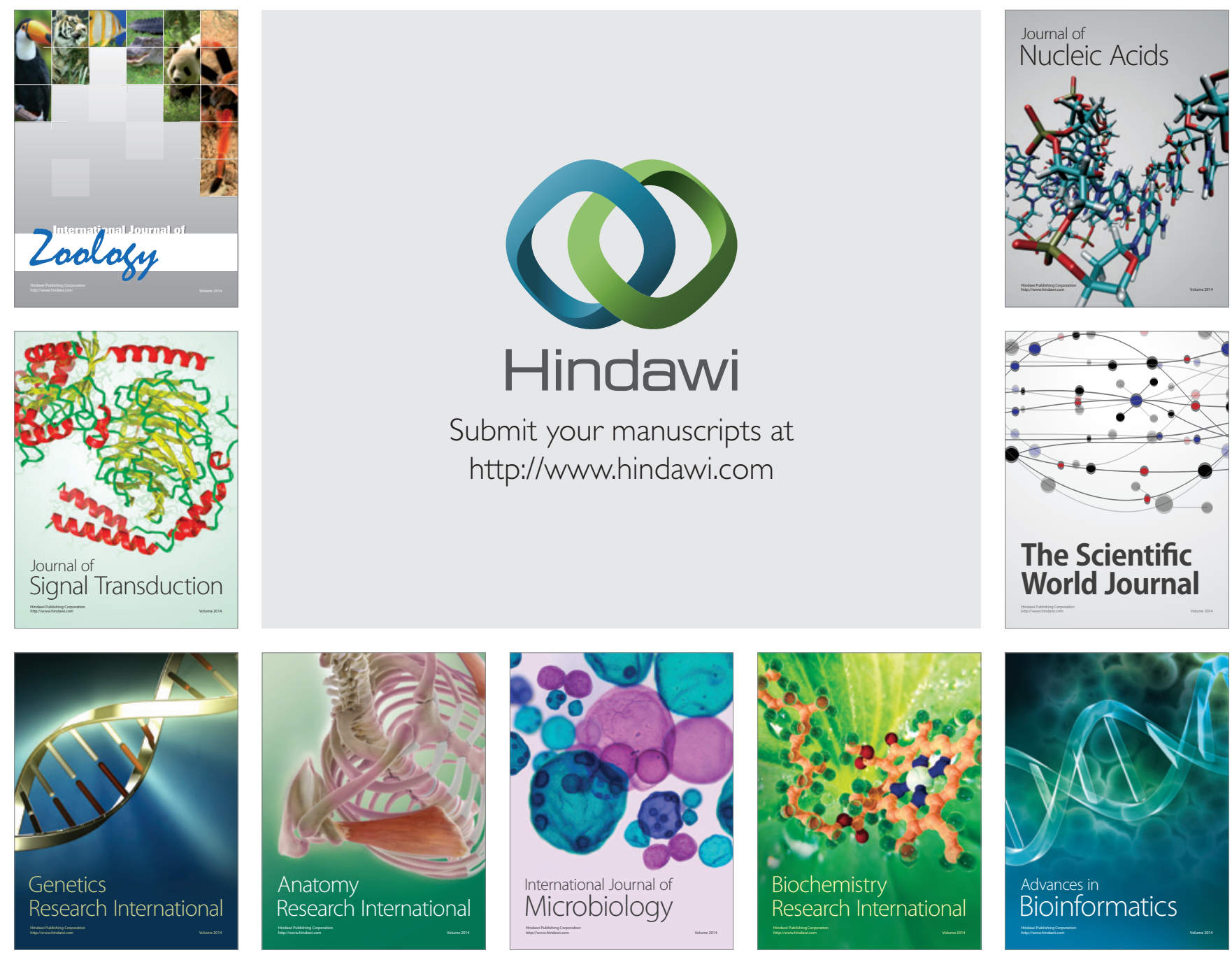

The Scientific World Journal
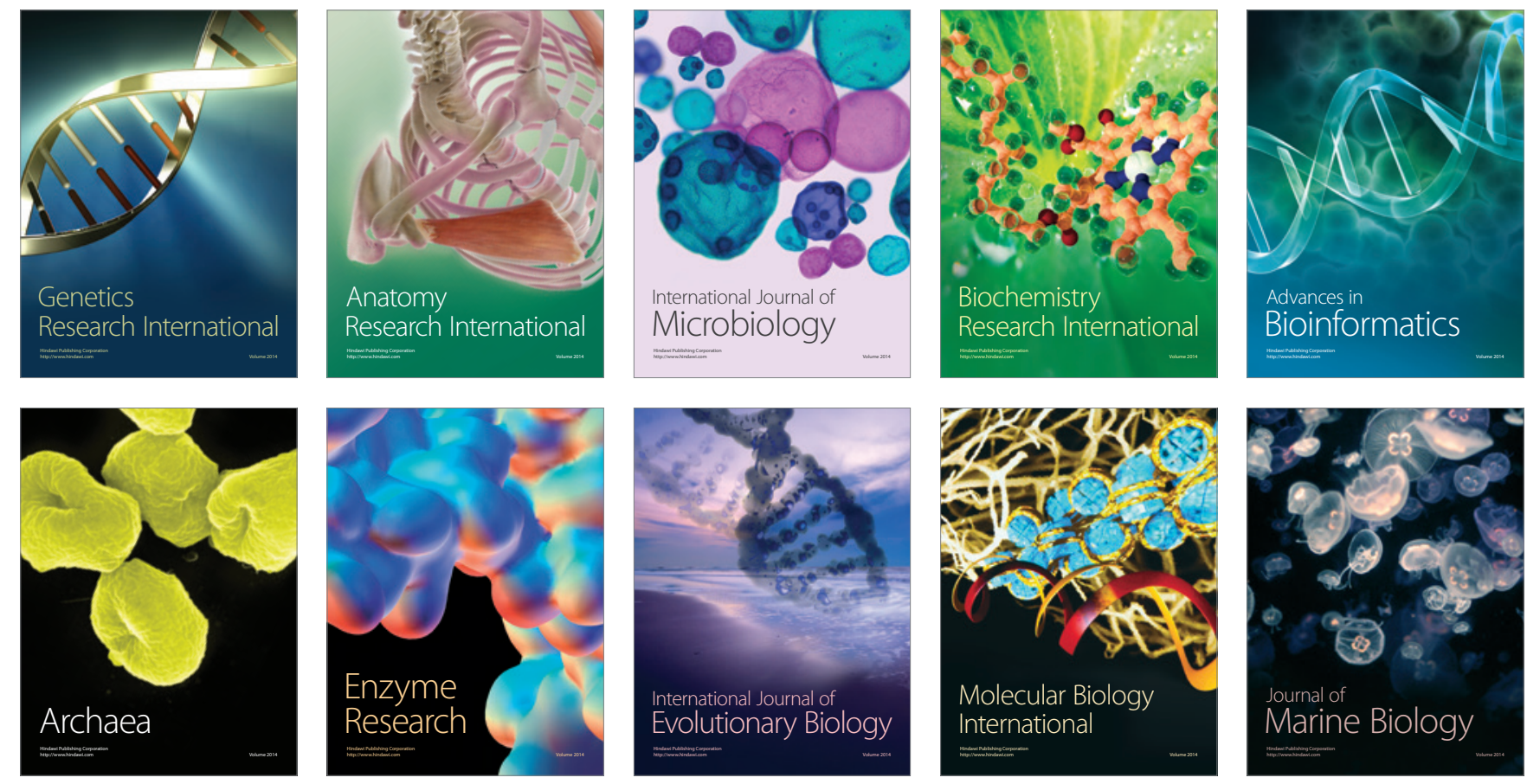